\title{
ISTICANJE POVREDA KONVENCIJSKIH I USTAVNIH PRAVA U POSTUPCIMA PRED REDOVNIM SUDOVIMA
}

\author{
Dr. sc. Sandra Marković* \\ Sanja Trgovac, dipl. iur.**
}

\author{
UDK: 341.645 \\ https://doi.org/10.30925/zpfsr.40.1.20 \\ Ur.: 8. siječnja 2019. \\ Pr.: 18. veljače 2019. \\ Pregledni znanstveni rad
}

\section{Sažetak}

Prema stajalištu Europskog suda za ljudska prava (u daljnjem tekstu: ESLJP) načelo supsidijarnosti jedno je od temeljnih načela na kojima se temelji konvencijski nadzorni sustav. Konkretno to znači da je mehanizam zaštite ljudskih prava $i$ temeljnih sloboda uspostavljen Konvencijom supsidijaran $u$ odnosu prema nacionalnim sustavima zaštite ljudskih prava. U radu se ističe protek vremena u kojem su sve strane u sudskim postupcima morale shvatiti i prihvatiti važnost primjene Konvencije za zaštitu ljudskih prava $i$ temeljnih sloboda, ali $i$ Ustava Republike Hrvatske u postupcima pred redovnim sudovima. Važnost ova dva dokumenta konkretizira se kroz odluke Ustavnog suda Republike Hrvatske i Europskog suda za ljudska prava, koji su svojom ulogom interpretatora Konvencije, odnosno Ustava jasno definirali sadržaje pojedinih ustavnih $i$ konvencijskih prava, sloboda, jamstava $i$ načela te stvorili putokaz za njihovu kvalitetniju zaštitu. Prednosti isticanja povreda konvencijskih i ustavnih prava već tijekom postupaka pred redovnim sudovima nesporna je, a u radu se ističe i njihova obveznost, u situacijama kada stranke svojim zahtjevima teže doći pred sudove na tim instancama. Autorice, baveći se karijerno ustavnim i konvencijskim pravom, prate razvoj prakse ovih sudova, posebno Ustavnog suda, pa tako $i$ uviđaju pooštravanje kriterija i jednog $i$ drugog suda za meritorno odlučivanje u pojedinačnim predmetima. U radu se stavlja naglasak na odluke Ustavnog suda i ESLJP-a u kojima je došlo do izražaja načelo supsidijarnosti. Pojašnjava se važnost ustavne tužbe i položaj ustavnog sudovanja u odnosu na redovne sudske postupke te se naglašava prijelaz Ustavnog suda na ustavnu argumentaciju umjesto redovnosudske, koja je prevladavala u ranijoj ustavnosudskoj praksi. U tom se kontekstu sagledava $i$ uočava još uvijek nedovoljno „,korištenje“ ustavnosudskih $i$ konvencijskih argumenata i pogrešna argumentacija ustavne tužbe i zahtjeva Europskom sudu za ljudska prava redovnim žalbenim razlozima.

* Dr. sc. Sandra Marković, odvjetnica, Zajednički odvjetnički ured dr. sc. Sandra Marković i Sidonija Grbavac; sandra.markovic@mgg-law.eu.

** Sanja Trgovac, dipl. iur., voditeljica Savjetničke službe Ustavnog suda RH; sanja_trgovac@ usud.hr. 
Ključne riječi: Ustavni sud; ESLJP; Konvencija, Ustav; načelo supsidijarnosti; Protokol 15; konvencijsko pravo; ustavno pravo; ustavna tužba; zahtjev ESLJP-u; argumentacija.

\section{1. $U V O D$}

Konvencija za zaštitu ljudskih prava i temeljnih sloboda ${ }^{1}$ stupila je na snagu u Republici Hrvatskoj 5. studenog 1997. Ustav Republike Hrvatske donesen je 1990. godine. ${ }^{2}$ Ističemo ove dvije činjenice kao uvod u ovaj rad, a njima naglašavamo protek vremena od stupanja na snagu ova dva dokumenta u Republici Hrvatskoj, čije sadržaje i primjenu u sudskoj praksi aktivno analiziramo preko dva desetljeća. Važnost primjene ova dva dokumenta pratimo kroz konkretne odluke Ustavnog suda Republike Hrvatske (u daljnjem tekstu: Ustavni sud) i Europskog suda za ljudska prava (u daljnjem tekstu: ESLJP), koji su kroz razvoj svoje prakse jasno definirali sadržaje pojedinih ustavnih i konvencijskih prava, sloboda, jamstava i načela te stvorili putokaz za njihovu kvalitetniju zaštitu. Prednosti isticanja povreda konvencijskih i ustavnih prava već tijekom postupaka pred redovnim sudovima prepoznali smo davno, a sada ističemo i njihovu obveznost, u situacijama kada stranke svojim zahtjevima teže doći pred sudove na tim instancama. Ustavni sud ni ESLJP više ne toleriraju nepoznavanje i neisticanje povrede Ustavom i Konvencijom zajamčenih prava i sloboda tijekom postupaka koji prethode ustavnosudskom postupku odnosno postupku pred ESLJPom. U radu stavljamo naglasak na odluke Ustavnog suda i ESLJP-a u kojima je došlo do izražaja načelo supsidijarnosti.

\section{VAŽNOST USTAVNE TUŽBE}

Ustavna tužba je institut uveden u hrvatski pravni sustav Ustavom iz 1990. godine. Napominjemo ovu činjenicu zato što kroz razvoj prakse Ustavnog suda pratimo i prijelaz od tolerantnijeg pristupa tog suda sadržaju ustavnih tužbi u početnim godinama prema strožem pristupu. Kriteriji kojima Ustavni sud procjenjuje argumentaciju ustavne tužbe zahtijeva od stranaka i njihovih punomoćnika više znanja ustavnog i konvencijskog prava i kvalitetnije ustavne tužbe odnosno argumentaciju primjerenu važnosti ustavnog sudovanja. Činjenica koja se često zaboravlja jest da ustavna tužba nije redovni ili izvanredni pravni lijek u sustavu domaćih pravnih lijekova. ${ }^{3}$ Slijedom navedenoga, i sadržaj ustavne tužbe razlikuje se od sadržaja pravnih lijekova i podnesaka koji su pisani do tog trenutka u postupku.

1 Konvencija za zaštitu ljudskih prava i temeljnih sloboda, Narodne novine - Međunarodni ugovori, broj 18/97., 6/99. - pročišćeni tekst, 8/99. - ispravak, 14/02. i 1/06., u daljnjem tekstu; Konvencija.

2 Ustav Republike Hrvatske donesen je na 10. skupnoj sjednici svih vijeća Sabora 21. prosinca 1990. te je proglašen na istoj sjednici drugog dana, 22. prosinca 1990. Vidi: Šarin, D., Nastanak hrvatskoga Ustava, Zagreb, Narodne novine, 1997. U ovom radu koristimo se redakcijski pročišćenim tekstom Ustava kojim se služi Ustavni sud Republike Hrvatske, Narodne novine 56/90., 135/97., 113/00., 28/01., 76/10. i 5/14.

3 V. rješenje broj: U-III-1747/2009 od 10. studenoga 2009., Narodne novine, broj 139/09. 
Razdoblje u radu Ustavnog suda koje karakterizira prihvaćanje i izgradnja europskih ustavnih standarda, kao i oslanjanje na jurisprudenciju ESLJP-a, u primjeni posebnih načela za interpretaciju Ustava i u prihvaćanju različitih sudskih tehnika za utvrđivanje ustavno relevantnog supstrata konkretnog slučaja i za njegovo rješavanje, otvara novi pristup i u odnosu na argumentaciju ustavne tužbe. Taj prijelaz Ustavnog suda na ustavnu argumentaciju umjesto redovnosudske, koja je u ranijoj ustavnosudskoj praksi prevladavala, postupan je i višegodišnji. ${ }^{4}$ Takav razvoj prakse Ustavnog suda u odlučivanju o ustavnim tužbama rezultirao je i većim postotkom nerazmatranja (odbačaja) onih ustavnih tužbi u kojima nisu navedeni ustavnopravni argumenti kojima bi se potkrijepila istaknuta povreda ustavnog prava, odnosno onih ustavnih tužbi u kojima su se podnositelji, nezadovoljni neuspjehom u sudskom postupku, ,zadržali“ na ponavljanju revizijskih ili žalbenih razloga. ${ }^{5}$ Često se, naime zanemaruje i da: Ustavni sud nije redovni sud trećeg ili četvrtog stupnja, ne provodi sudski postupak i ne odlučuje meritorno o pravima ili obvezama stranaka ni o sumnji ili optužbi za kaznena djela u pojedinačnim slučajevima. ${ }^{6}$ Ustavni sud posebno je tijelo utemeljeno Ustavom radi zaštite pojedinačnih ljudskih prava i temeljnih sloboda (ustavnih prava) u postupku pokrenutom ustavnom tužbom. ${ }^{7}$

\section{OPĆENITO O NAČELU SUPSIDIJARNOSTI U PRAKSI USTAVNOG SUDA I ESLJP-A}

Ustavni sud u postupcima pokrenutim ustavnim tužbama ima zadaću osigurati da se nadležna tijela državne i javne vlasti pridržavaju svojih obveza osiguravanja ljudskih prava i temeljnih sloboda zajamčenih u Ustavu (članak 125. alineja 4.). Pritom se „cjelokupno hrvatsko pravo mora tumačiti u skladu s pravnim standardima koje u svojoj sudskoj praksi stvara Europski sud, sve dok je Republika Hrvatska članica Vijeća Europe, što znači sve dok je dio svoje sudbene jurisdikcije vlastitom suverenom odlukom prenijela na Europski sud." ${ }^{8}$ To je obveza ne samo Ustavnog suda (da u postupcima pokrenutim ustavnim tužbama primjenjuje pravne standarde koje je u svojoj praksi izgradio Europski sud), „,već to je prije svega obveza redovnih sudova na čelu s Vrhovnim sudom kao najvišim sudom, nadležnim za osiguravanje jedinstvene primjene prava i ujednačavanje sudske prakse". ${ }^{9}$

4 Kao jednu točku tog prijelaza možemo naznačiti kraj 2009. godine, kada je Ustavni sud uveo novi način „trijažiranja“ ustavnih tužbi, kroz „meritorni kriterij“. Više u: Marković, S., Trgovac, S., Nova praksa u postupanju Ustavnog suda Republike Hrvatske, Pretpostavke za odlučivanje o ustavnim tužbama, Informator, broj 5844, od 10. ožujka 2010.

5 Više: Marković, S., Trgovac, S., Ustavna tužba i zahtjev Europskom sudu za ljudska pravaanaliza i značaj tih pravnih sredstava“, u: Aktualnosti hrvatskog zakonodavstva i pravne prakse, Godišnjak 25, Zagreb, Organizator, 2018.

6 V. odluku broj: U-III-4150/2010 i dr. od 12. siječnja 2015. (t. 214. obrazloženja), Narodne novine, broj 6/15.

7 V. rješenje navedeno u bilješki 3

8 V. odluku broj: U-I- U-I-448/2009 i dr. od 19. srpnja 2012., Narodne novine, broj 91/12., t. 121.7. obrazloženja.

9 V. rješenje broj: U-III-1118/2015 od 30. ožujka 2016. (www.usud.hr). 
Prema članku 115. stavku 3. Ustava sudovi sude na temelju Ustava, zakona, međunarodnih ugovora i drugih važećih izvora prava. Primarnu zaštitu ustavnih i konvencijskih prava pružaju dakle redovni sudovi, dok je uloga Ustavnog suda supsidijarna. Ustavni sud će u pojedinačnim slučajevima ukinuti presude ako su sudovi pri tumačenju i primjeni propisa zanemarili ustavna prava podnositelja odnosno ustavna načela (Primjerice u predmetu U-III-1897/2014, vezanom za parnicu radi povrata rekviriranog vozila, Ustavni sud je utvrdio da je nadležni drugostupanjski sud: „,ignorirao ustavni i konvencijski zahtjev za postizanjem pravedne ravnoteže između općeg interesa države i zaštite imovinskih prava podnositelja (...) On je interpretirao podnositeljev tužbeni zahtjev uz potpuno zanemarivanje osnovnog pravila pravnog poretka utemeljenog na vladavini prava i zaštiti ljudskih prava: da je svrha sudske zaštite jamčiti pojedincima prava koja su provediva u praksi i djelotvorna, a ne ona koja su teorijska ili prividna (iluzorna).). ${ }^{10}$

U tom je smislu i ustavnu tužbu, kao i zahtjev ESLJP-u, dopušteno podnijeti tek nakon iscrpljivanja pravnog puta. ${ }^{11}$ Svrha inzistiranja na iscrpljivanju dopuštenoga pravnog puta ne samo u vidu pukog korištenja dopuštenih pravnih lijekova već i isticanja prigovora pred redovnim sudovima koji se kasnije ističu u ustavnoj tužbi ili zahtjevu ESLJP-u jest omogućavanje redovnim sudovima, odnosno Ustavnom sudu ispraviti eventualne ,pogreške”, odnosno povrede ustavnih i konvencijskih prava: „Prigovor u smislu članka 36. stavka 2. ZKP-a (pristranosti suca - op. autorica) podnositelj je prvi put istaknuo u ustavnoj tužbi, pa bi se, imajući u vidu činjenicu da je tijekom trajanja kaznenog postupka imao, i propustio, dvije prigode za isticanje takvih prigovora, podnositeljeva ustavna tužba u tom dijelu morala odbaciti zbog nedopuštenosti. Pritom Ustavni sud podsjeća na svoju odluku, broj: U-III-857/2008 od 1. listopada 2008., u kojoj je izrekao stajalište da je podnositelj, koji je pred redovnim sudom propustio iznijeti prigovore postupovne naravi, koje iznosi tek u ustavnoj tužbi, bitno umanjio mogućnost redovnih sudova da reagiraju na eventualne povrede zakona, uslijed čega činjenica neiscrpljenosti pravnog puta još više poprima na važnosti." ${ }^{\prime 2}$ Kako bi se ispunila pretpostavka iscrpljivanja domaćih pravnih sredstava, a u skladu s načelom supsidijarnosti, podnositelji moraju, prije nego što podnesu svoje prigovore Sudu, prvo dati hrvatskom Ustavnom sudu, kao najvišem sudu u Hrvatskoj, priliku da ispravi njihovu situaciju i riješi pitanja koja žele podastrijeti Sudu." ${ }^{13}$

10 V. odluku broj: U-III-1897/2014 od 18. svibnja 2016. (www.usud.hr).

11 Članak 62. stavak 2. Ustavnog zakona o Ustavnom sudu Republike Hrvatske, Narodne novine, broj 99/99., 29/02. i 49/02. - pročišćeni tekst, u daljnjem tekstu: Ustavni zakon, glasi: „Ako je zbog povrede ustavnih prava dopušten drugi pravni put, ustavna tužba može se podnijeti tek nakon što je taj pravni put iscrpljen.“. Članak 35. stavak 1. Konvencije glasi: „Sud može razmatati predmet samo nakon što su iscrpljena sva raspoloživa domaća pravna sredstva, u skladu s općeprihvaćenim pravilima međunarodnog prava i unutar razdoblja od šest mjeseci od dana donošenja konačne odluke."

12 Odluka broj: U-III-2374/2009 od 4. listopada 2010., Narodne novine, broj 119/10., t. 9. obrazloženja.

13 V. predmet ESLJP-a Jurić protiv Hrvatske (odluka od 26. lipnja 2018., zahtjev br. 29843/13, $\S 19$.$) .$ 


\subsection{Praksa Europskog suda za ljudska prava}

Prema stajalištu ESLJP-a načelo supsidijarnosti jedno je od temeljnih načela na kojima se temelji konvencijski nadzorni sustav. To znači da je mehanizam zaštite ljudskih prava i temeljnih sloboda uspostavljen Konvencijom supsidijaran u odnosu prema nacionalnim sustavima zaštite ljudskih prava. Pritom „Konvencija ne postavlja državama članicama niti jedan zadani način na koji bi u svojem unutarnjem pravu trebale osigurati djelotvornu provedbu Konvencije. Izbor najprikladnijeg sredstva da se to postigne u načelu je na domaćim vlastima, koje su u stalnom kontaktu s djelatnim vlastima svojih zemalja i u boljem su položaju da ocjene mogućnosti i resurse koje im daju njihovi domaći pravni sustavi". ${ }^{14}$

U presudama Vučković i drugi protiv Srbije ${ }^{15}$ i Gherghina protiv Rumunjske ${ }^{16}$ ESLJP je sažeo svoja stajališta vezana za načelo supsidijarnosti. Između ostalog, pravilo o iscrpljivanju domaćih pravnih sredstava usko je povezano s člankom 13. Konvencije, ${ }^{17}$ a temelji se na pretpostavci da u državi članici postoji djelotvorno pravno sredstvo za sprječavanje ili ispravljanje navodne povrede konvencijskog prava. To pravno sredstvo mora biti dostupno i dostatno, dovoljno izvjesno ne samo u teoriji već i u praksi, i mora biti sposobno izravno spriječiti ili ispraviti povredu konvencijskog prava te pružiti razumne izglede za uspjeh. Ako na nacionalnoj razini postoji pravno sredstvo koje domaćim sudovima omogućuje da, barem u biti, ispitaju tvrdnju o povredi nekoga konvencijskog prava, onda je to pravno sredstvo koje treba iscrpiti. Pritom nije dovoljno da podnositelj zahtjeva neuspješno upotrijebi neko drugo pravno sredstvo, koje bi, doduše, moglo utjecati na ishod spora i izmijeniti osporenu mjeru, ali na drugoj osnovi, koja nema veze s prigovorom o povredi konvencijskog prava. ${ }^{18}$

U tom smislu podnositeljima se nameće obveza prije podnošenja zahtjeva ESLJP-u iskoristiti djelotvorna pravna sredstva koja imaju na raspolaganju u svom nacionalnom pravnom poretku. Ta obveza zahtijeva od podnositelja da se tim sredstvima posluže na uobičajeni način, u skladu s formalnim zahtjevima domaćeg prava i u propisanim rokovima. Prigovor koji se podnosi ESLJP-u mora se, barem u biti, iznijeti pred domaće sudove. Potrebno je također koristiti sva procesna sredstva

14 V. predmet ESLJP-a Srbić protiv Hrvatske (odluka od 21. lipnja 2011., zahtjev br. 4464/09), v. i odluke na koje se u predmetu Srbić protiv Hrvatske ESLJP pozvao: Swedish Engine Drivers' Union protiv Švedske, od 6. veljače 1976. godine, stavak 50., Serija A br. 20; Chapman protiv Ujedinjenog Kraljevstva [GC], br. 27238/95, stavak 91., ESLJP 2001-I i Sisojeva and Others protiv Latvije [GC], br. 60654/00, stavak 90., ESLJP 2007-II.

15 Predmet Vučković i drugi protiv Srbije (presuda Velikog vijeća od 25. ožujka 2014., zahtjevi br. 17153/11 i dr.).

16 Predmet Gherghina protiv Rumunjske (presuda Velikog vijeća od 9. srpnja 2015., zahtjev br. 42219/07).

17 Članak 13. Konvencije glasi:

„Pravo na djelotvoran pravni lijek

Svatko čija su prava i slobode koje su priznate u ovoj Konvenciji povrijeđene ima pravo na djelotvorna pravna sredstva pred domaćim tijelom čak i u slučaju kad su povredu počinile osobe koje su djelovale u službenom svojstvu."

18 Predmet Jureša protiv Hrvatske (odluka od 22. svibnja 2018., zahtjev br. 24079/11, §19.). 
koja mogu spriječiti povredu Konvencije.

$\mathrm{Ne}$ postoji, međutim, obveza korištenja onih pravnih sredstava koja su neodgovarajuća ili neučinkovita. Uz to, mogu postojati posebne okolnosti koje oslobađaju podnositelje od iscrpljivanja domaćega pravnog sredstva (primjerice u repetitivnim slučajevima). Pravilo o iscrpljivanju pravnog puta ESLJP primjenjuje $\mathrm{s}$ određenim stupnjem fleksibilnosti i bez pretjeranog formalizma (primjerice neće zahtijevati iscrpljivanje toga pravnog sredstva, ako ni sam najviši sud u državi ne zahtijeva od podnositelja njegovo iscrpljivanje).

U ovom radu prikazat ćemo navedeno kroz odluke i presude ESLJP-a, donesene u predmetima protiv Hrvatske u kojima su primijenjena navedena stajališta ESLJP-a.

\subsubsection{Odluka Merot d.o.o. i Storitve Tir d.o.o. protiv Hrvatske ${ }^{19}$}

U zahtjevu ESLJP-u društva Merot d.o.o. i Storitve Tir d.o.o. prigovarala su tomu što su im u prekršajnom postupku vođenom protiv brodara (trgovačkog društva) i odgovorne osobe u tom trgovačkom društvu, oduzete njihove jahte. Podnositelji su također prigovarali, na temelju članka 6 . stavka 1 . Konvencije, da prekršajni postupak nije bio pošten te, na temelju članka 13. Konvencije, da nisu imali djelotvorno pravno sredstvo jer im je prvostupanjsko rješenje od 31. kolovoza 2005. dostavljeno tek po njihovom zahtjevu i tek nakon što je Visoki prekršajni sud Republike Hrvatske već odbio žalbu okrivljenika protiv tog rješenja. Iako se podnositelji nisu pozvali na povredu članka 1. Protokola br. 1 uz Konvenciju, koji jamči pravo vlasništva, ESLJP je ocijenio da prigovor o oduzimanju jahti koje su vlasništvo podnositelja treba razmatrati s aspekta toga članka.

Vlada Republike Hrvatske tvrdila je da podnositelji nisu iscrpili dopušteno pravno sredstvo. Trebali su podnijeti tužbu radi naknade štete protiv brodara i u ustavnim tužbama, a niti tijekom postupka koji im je prethodio, nisu isticali povredu prava vlasništva. Vezano za prvi navod, ESLJP je utvrdio da je nad tim društvom otvoren stečajni postupak 26. lipnja 2008. te bi podnošenje građanske tužbe protiv njega bilo bezuspješno. Vezano za drugu tvrdnju Vlade, ESLJP je prvo utvrdio da se podnositelji u svojim ustavnim tužbama doista nisu pozivali na članak 48. Ustava, odnosno članak 1. Protokola br. 1 uz Konvenciju, niti su u biti istaknuli povredu prava vlasništva. Umjesto toga, u ustavnim tužbama isključivo su prigovarali različitim postupovnim pogreškama, a ne oduzimanju njihovih jahti. Štoviše, u odgovoru na tvrdnje Vlade o neiscrpljivanju pravnog puta podnositelji nisu ni pokušali tvrditi da su svojim ustavnim tužbama u biti prigovarali povredi njihova prava vlasništva. Umjesto toga, u odgovoru su se ograničili na tvrdnju da iz sadržaja tih ustavnih tužbi proizlazi da je oduzimanje jahti imalo za posljedicu povredu njihova prava vlasništva. Prema stajalištu ESLJP-a činjenica da su podnositelji iznijeli svoj slučaj pred različite nadležne sudove ne znači samo po sebi udovoljavanje zahtjevu iz članka 35. stavka 1. Konvencije, jer čak niti u pravnom sustavu u kojem domaći sudovi imaju mogućnost, ili čak obvezu, ispitati slučaj po službenoj dužnosti (što Ustavni sud Republike Hrvatske nema), podnositelji nisu oslobođeni isticanja prigovora pred tim sudovima

19 Predmet Merot d.o.o. i Storitve TIR d.o.o. (odluka od 10. prosinca 2013., zahtjevi br. 29426/08 i 29737/08). 
prije nego ih potom iznesu pred ESLJP-om. Stoga, kako bi pravilno iscrpili domaća pravna sredstva nije dostatno da povreda Konvencije ,proizlazi“ iz činjenica predmeta ili podnesaka podnositelja. Umjesto toga, oni moraju stvarno iznijeti prigovor o tome (izričito ili u biti) na način koji ne ostavlja sumnju da je prigovor, koji je kasnije podnesen ESLJP-u, stvarno bio istaknut na domaćoj razini.

ESLJP je naveo da podnositelji nisu tvrdili da bi prigovor pred Ustavnim sudom koji bi se odnosio na oduzimanje njihovih jahti bio lišen ikakve šanse za uspjeh. Praksa Ustavnog suda, s druge strane, pokazuje da taj sud razmatra razmjernost mjere oduzimanja predmeta kada je na to pozvan. ESLJP je ocijenio da podnositelji nisu pravilno iscrpili domaća pravna sredstva, odnosno nisu dala domaćim tijelima priliku da razmotre i spriječe ili isprave određenu povredu Konvencije koja se protiv njih iznosi. Ovaj je prigovor odbačen zbog neiscrpljivanja domaćih pravnih sredstava. ${ }^{20}$

\subsubsection{Odluka Josip Habulinec i Anita Filipović protiv Hrvatske ${ }^{21}$}

U zahtjevu ESLJP-u podnositelji, izvanbračni drugovi, prigovarali su zbog nemogućnosti upisivanja u matičnu knjigu rođenih prvog podnositelja kao oca djeteta koje je umrlo dan nakon rođenja, budući da se ne može priznati očinstvo mrtvog djeteta. Prigovarali su na temelju članka 8. Konvencije (pravo na privatni i obiteljski život) zasebno i zajedno s člankom 14. Konvencije (zabrana diskriminacije), u usporedbi s roditeljima djece rođene $\mathrm{u}$ braku.

U odnosu na prigovor Vlade o neiscrpljenosti pravnog puta ESLJP je utvrdio da su podnositelji Matičnom uredu predali pisani zahtjev za upis očinstva prvog podnositelja te da na njihov zahtjev nije odgovoreno nikakvom formalnom odlukom. Prema ocjeni ESLJP-a, podnositelji su mogli koristiti sredstva zbog šutnje administracije. S obzirom na dvojbe podnositelja o izgledima za uspjeh bilo kojeg od tih pravnih sredstava vezanih za šutnju administracije, ESLJP je ponovio da samo postojanje dvojbi o djelotvornosti domaćega pravnog sredstva ne oslobađa automatski podnositelja obveze iscrpljivanja tog sredstva.

Nadalje, ESLJP je naveo da je Konvencija sastavni dio hrvatskoga pravnog sustava, $\mathrm{u}$ kojem ima prednost pred svakom suprotnom zakonskom odredbom ${ }^{22}$ te je izravno primjenjiva (članak 5. Zakona o sudovima ${ }^{23}$ ). S tim u vezi ESLJP je naveo

20 V. primjerice i predmete Godler protiv Hrvatske (odluka od 20. veljače 2018., zahtjev br. 9440/12) vezano za pravo vlasništva i Jurišić protiv Hrvatske (odluka od 23. kolovoza 2016., zahtjev br. 29555/11) vezano uz pravo na poštovanje privatnog života (članak 8. Konvencije). V. i suprotno tome, predmete Paulić protiv Hrvatske (presuda od 22. listopada 2009., zahtjev br. 3572/06, § 26) i Orlić protiv Hrvatske (presuda od 21. lipnja 2011., zahtjev br. 48833/07, § 41), oba vezana uz pravo na dom (članak 8 . Konvencije).

21 Predmet Josip Habulinec i Anita Filipović protiv Hrvatske (odluka od 4. lipnja 2013., zahtjev br. 51166/10).

22 U redakcijski pročišćenom tekstu Ustava riječ je o članku 134. koji glasi:

„Međunarodni ugovori koji su sklopljeni i potvrđeni u skladu s Ustavom i objavljeni, a koji su na snazi, čine dio unutarnjega pravnog poretka Republike Hrvatske, a po pravnoj su snazi iznad zakona. Njihove se odredbe mogu mijenjati ili ukidati samo uz uvjete i na način koji su u njima utvrđeni ili suglasno općim pravilima međunarodnog prava."

23 Zakon o sudovima, Narodne novine, broj 3/94., 100/96., 131/97., 129/00., 17/04. i 141/04. 
da je njegova sudska praksa sastavni dio sustava Konvencije. Također je istaknuo da je već rješavao sličnu situaciju, u predmetu Znamenskaya protiv Rusije. ${ }^{24}$ Središnje pitanje u tom predmetu bila je nemogućnost podnositeljice da dobije priznanje da je g. G. biološki otac njezinoga mrtvog djeteta. ESLJP je utvrdio povredu članka 8. Konvencije u tom predmetu. Presuda u predmetu Znamenskaya donesena je prije nego što je nastala situacija kojoj su prigovarali podnositelji u ovom predmetu. ESLJP je smatrao da su podnositelji, pozivom na utvrđenja ESLJP-a u predmetu Znamenskaya, mogli tvrditi pred nacionalnim vlastima da im je, u danim okolnostima, povrijeđeno njihovo pravo na poštovanje njihova privatnog i obiteljskog života, protivno članku 8. Konvencije. Mogli su i iznijeti svoje tvrdnje o članku 14. Konvencije, jer hrvatski Ustav jamči i pravo ne biti diskriminiran. Tada bi nacionalne vlasti, uključujući i Ustavni sud, mogle odgovoriti na te tvrdnje podnositelja. ESLJP je istaknuo da je Ustavni sud u svojim odlukama zauzeo stajalište da se prava zajamčena Konvencijom i njezinim protokolima imaju smatrati ustavnim pravima s pravnom snagom jednakom odredbama Ustava te je tako priznao svoju nadležnost za ispitivanje navodnih povreda Konvencije. S obzirom na to, tvrdnja podnositelja da nisu imali izgleda za uspjeh zbog zakonske odredbe koja sprječava upis očinstva, prema ocjeni ESLJP-a, ima manju važnost, jer u hrvatskom pravnom sustavu Konvencija ima prvenstvo pred domaćim zakonima. ESLJP je zaključio da su podnositelji trebali, u skladu s načelom supsidijarnosti, prije podnošenja svog zahtjeva ESLJP-u, izložiti svoje tvrdnje pred nacionalnim vlastima $\mathrm{i}$ tako im dati priliku za ispravljanje njihove situacije, osobito pred Ustavnim sudom kao najvišim sudom u Hrvatskoj. Ovaj dio zahtjeva ESLJP je odbacio zbog neiscrpljenja domaćih pravnih sredstava.

\subsubsection{Odluka Šimunovski protiv Hrvatske ${ }^{25}$}

Podnositelj zahtjeva ESLJP-u prigovorio je na temelju članka 3. Konvencije općim uvjetima u kojima je bio zatvoren u raznim zatvorima. Prigovorio ja na temelju članka 8. Konvencije da mu je povrijeđeno pravo na poštovanje njegovog dopisivanja i da je bio lišen i privatnih bračnih posjeta i prava na korištenje osobnog računala. Na temelju članka 10. Konvencije i na temelju članka 1. Protokola br. 1 prigovorio je da zatvorenicima nisu bile osigurane nikakve novine i da nije mogao podizati svoju mirovinu, koja mu je bila uplaćivana na njegov bankovni račun.

ESLJP je utvrdio da podnositelj nije ni jednom nadležnom sucu podnio detaljne i konkretne prigovore o materijalnim uvjetima u kojima je bio zatvoren, u odnosu na razdoblje u kojem je bio zatvoren do 5. lipnja 2009. O uvjetima u kojima je podnositelj zahtjeva bio zatvoren nakon 5. lipnja 2009. u svojim je podnescima upućenim istražnom sucu Županijskog suda u Varaždinu prigovorio uvjetima u kojima je zatvoren. Podrobno je opisao svoju ćeliju i naveo da je bio u samici. Taj se prigovor smatrao žalbom na odluku upravitelja KL-a od 23. lipnja 2009. godine te je utvrđeno da je nepravodobna. Podnositelj nije podnio ustavnu tužbu protiv te odluke.

ESLJP je nadalje primijetio da podnositelj nije podnio ustavnu tužbu u odnosu na odluke koje se tiču njegovog dopisivanja, a koje su donijeli sudac izvršenja

24 Predmet Znamenskaya protiv Rusije (presuda od 2. lipnja 2005., zahtjev br. 77785/01).

25 Predmet Šimunovski protiv Hrvatske (odluka od 21. lipnja 2011., zahtjev br. 42550/08). 
Županijskog suda u Varaždinu 4. prosinca 2007. i 23.listopada2008.isudacizvršenja Županijskog suda u Šibeniku 27. ožujka 2008. U odnosu na odluke upravitelja KL-a, kojima je spriječio podnositelja zahtjeva da pošalje pisma, podnositelj nije podnio žalbu sucu izvršenja. Podnositelj nije ESLJP-u dostavio dokaz da je prigovorio sucu izvršenja Županijskog suda u Šibeniku zbog odbijanja dozvole za privatne bračne posjete tijekom njegovog boravka kao zatvorenika u zatvoru u Šibeniku. U odnosu na lišenje prava na korištenje osobnog računala podnositelj nije podnio ustavnu tužbu protiv odluke suca izvršenja Županijskog suda u Varaždinu kojom mu se to pravo ne odobrava. Konačno, ESLJJP je utvrdio da podnositelj nije naveo jasne i razumljive prigovore sucu izvršenja koji bi se odnosili na navode o povredi članka 10. i članka 1. Protokola br. 1 uz Konvenciju. Prema ocjeni ESLJP-a podnositelj je propustio pravilno iscrpiti dostupna domaća pravna sredstva u odnosu na sve prigovore te tako protivno načelu supsidijarnosti nije dao priliku nacionalnim vlastima da isprave situaciju kojoj prigovara pred ESLJP-om.

\subsubsection{Presuda Pavlović i dr. protiv Hrvatske ${ }^{26}$}

Podnositeljice su bile tužiteljice u parničnom postupku u kojem su tražile iseljenje stanara iz stana u njihovom vlasništvu i uklanjanje svih građevinskih zahvata na tom stanu. Tuženik je protutužbom tražio sklapanje ugovora o najmu stana sa zaštićenom najamninom ili povrat sredstava na osnovi ulaganja u stan. Na ročištu na kojem je zaključena glavna rasprava podnositeljice su tražile naknadu parničnih troškova te su priložile u spis troškovnik. Općinski sud naložio je iseljenje tuženika. Ostale zahtjeve sud je odbio. U vezi s troškovima presudio je da svaka stranka snosi svoj trošak. U žalbenom postupku podnositeljice su osporile odluku prvostupanjskog suda u dijelu u kojem je odlučeno o trošku parničnog postupka. Drugostupanjski sud odbio je žalbu podnositeljica. Istaknuo je da podnositeljicama doista pripada parnični trošak, no kako nisu postupile sukladno članku 164. stavku 3. Zakona o parničnom postupku i do završetka rasprave dostavile troškovnik (kako to proizlazi „,iz stanja spisa”), trošak im nije mogao biti dosuđen. Ustavnu tužbu podnositeljica podnesenu u povodu drugostupanjske presude Ustavni sud je odbacio sukladno svojoj dugogodišnjoj praksi (od 2003. godine) prema kojoj odluka o parničnom trošku nije pojedinačni akt u smislu članka 62. stavka 1. Ustavnog zakona, u povodu kojeg bi Ustavni sud bio nadležan pružiti ustavnosudsku zaštitu.

Uzahtjevupodnesenom ESLJP-u podnositeljicesu istaknule daje drugostupanjski sud propustio pažljivo proučiti spis jer su one uredno priložile troškovnik. Istaknule su povredu prava na pošteno suđenje i prava na mirno uživanje vlasništva.

Vlada je tvrdila da je konačna odluka u predmetu podnositeljica zahtjeva bila drugostupanjska presuda Županijskog suda u Rijeci od 2. veljače 2010., a ne odluka Ustavnog suda od 23. rujna 2010., budući da su podnositeljice zahtjeva, koje je zastupao odvjetnik, trebale znati da prema praksi Ustavnog suda ustavna tužba nije pravno sredstvo koje treba koristiti u pogledu troškova postupka. Prema Vladi, to je bilo jasno od 3. listopada 2003. kad je Ustavni sud objavio svoju odluku br.

26 Predmet Pavlović i dr. protiv Hrvatske (presuda od 2. travnja 2015., zahtjev br. 13274/11). 
U-III-402/2002 od 12. rujna 2003. u Narodnim novinama. Vlada je smatrala da se podnositeljice, pozivajući se na rješenje Ustavnog suda kao konačnu domaću odluku i podnoseći zahtjev ESLJP-u 3. veljače 2011., nisu pridržavale šestomjesečnog roka.

ESLJP je istaknuo da su zahtjevi sadržani u članku 35. stavku 1. Konvencije koji se tiču iscrpljivanja domaćih pravnih sredstava i šestomjesečni rok u bliskom međusobnom odnosu, jer nisu samo navedeni $u$ istome članku nego su izrečeni $u$ jednoj rečenici čije gramatičko tumačenje podrazumijeva takav međusobni odnos. ${ }^{27}$

U pravilu, šestomjesečni rok teče od datuma posljednje, konačne odluke donesene u postupku iscrpljivanja domaćih pravnih sredstava. Prema stajalištu ESLJP-a, članak 35. stavak 1. Konvencije ne može se tumačiti na način koji bi zahtijevao da podnositelj obavijesti ESLJP o svom prigovoru prije nego što je njegov položaj u vezi s tim pitanjem konačno riješen na domaćoj razini.

Prema ustaljenoj praksi ESLJP-a odluke koje se odnose na troškove postupka spadaju u opseg članka 6 . Konvencije. ${ }^{28}$

S obzirom na tvrdnju Vlade da ustavna tužba nije bila pravno sredstvo koje treba iscrpiti u svrhu izračuna šestomjesečnog roka, ESLJP je ponovio da je kontinuirano smatrao da se prije podnošenja prigovora protiv Hrvatske ESLJP-u, kako bi bio u skladu s načelom supsidijarnosti, od podnositelja u načelu zahtijeva da Ustavnom sudu, kao najvišem sudu u Hrvatskoj, daju priliku da popravi situaciju u kojoj se nalazi. ${ }^{29} \mathrm{U}$ brojnim prijašnjim predmetima $u$ kojima je postupao $\mathrm{s}$ istim prigovorom Vlade, ESLJP je primijetio da na temelju članka 62. Ustavnog zakona svatko može podnijeti ustavnu tužbu ako smatra da mu je pojedinačnim aktom tijela državne vlasti, kojim je odlučeno o njegovim pravima i obvezama ili o sumnji ili optužbi zbog kažnjivog djela, povrijeđeno ljudsko pravo ili temeljna sloboda zajamčena Ustavom. Prema tomu, kad god je podnositelj podnio ustavnu tužbu, ističući prigovore koji spadaju u opseg konvencijskog prava, ESLJP je smatrao, bez obzira na moguću odluku Ustavnog suda, da podnošenje ustavne tužbe nije nerazumno korištenje toga pravnog sredstva. Ne namjeravajući ispitivati kriterije Ustavnog suda za ocjenu dopuštenosti ustavnih tužbi, ESLJP je polazeći od svoje ranije prakse prema kojoj se smatra da je podnositelj Ustavnom sudu dao priliku popraviti situaciju u kojoj se nalazi, neovisno o praksi Ustavnog suda, a imajući u vidu tekst članka 62. Ustavnog zakona, činjenica da su podnositeljice zahtjeva podnijele ustavnu tužbu protiv drugostupanjske presude Županijskog suda u Zagrebu, ne smije se ni na koji način uzeti protiv njih. U tim okolnostima, ES L JP je smatrao da su podnositeljice propisno iskoristile dostupna domaća pravna sredstva.

27 V. bilj. 11.

28 ESLJP se pozvao na sljedeću praksu: „Robins protiv Ujedinjene Kraljevine, 23. rujna 1997., $\S \S 28$. i 29., Izvješća o presudama i odlukama 1997-V; Nikolay Matveyev protiv Rusije, br. 10418/04, § 31., 25. studenoga 2010. i Ležaja protiv Hrvatske (odl.), br. 53004/08, § 24. , 17. travnja 2012.)."

29 ESLJP se pozvao na sljedeću praksu: “Orlić, § 46.; Čamovski protiv Hrvatske, br. 38280/10, $\S$ 27., 23. listopada 2012.; Bajić protiv Hrvatske, br. 41108/10, § 66., 13. studenoga 2012.; Remetin protiv Hrvatske, br. 29525/10, § 81., 11. prosinca 2012.; Tarbuk protiv Hrvatske, br. 31360/10, § 29., 11. prosinca 2012.; Damjanac protiv Hrvatske, br. 52943/10, § 70, 24. listopada 2013. i Šimecki protiv Hrvatske, br. 15253/10, § 29., 30. travnja 2014.” 
Na sličnu situaciju u presudi Vrtar protiv Hrvatske ${ }^{30}$ ESLJP je još i dodao da je ustavna tužba, s obzirom na svoja svojstva, ,pravno sredstvo kojim se očito može očitovati o relevantnom pitanju Konvencije i dobiti zadovoljština za povredu koja je predmet prigovora". Smatrati da se takvo pravno sredstvo nije smjelo iskoristiti samo zato što u to vrijeme prema praksi Ustavnog suda osporeni akt nije pojedinačni akt u povodu kojeg se može podnijeti ustavna tužba, ignoriralo bi činjenicu da se takva praksa može razvijati, ali bi i uklonilo svaki poticaj za takav razvoj jer bi podnositelji zahtjeva sustavno upućivali svoje pritužbe ESLJP-u ne dajući priliku Ustavnom sudu da promijeni svoju praksu. To bi bilo protivno načelu supsidijarnosti.

\subsubsection{Odluka Vilić protiv Hrvatske ${ }^{31}$}

Podnositelji su tijekom 2002. pokrenuli parnični postupak radi naknade štete protiv Republike Hrvatske jer je njihova kuća od 1995. do 2000. bila dana na korištenje trećim osobama na temelju Zakona o privremenom preuzimanju i upravljanju određenom imovinom. ${ }^{32}$ Sudovi su odbili tužbeni zahtjev jer podnositelji nisu dokazali ni navodnu štetu ni visinu štete. Postupak se vodio dva puta na tri razine nadležnosti. Iako je vrijednost predmeta spora ostala nepromijenjena tijekom cijeloga postupka, Vrhovni sud Republike Hrvatske reviziju podnositelja jednom je odbio, a drugi put odbacio kao nedopuštenu ratione valoris. U ustavnoj tužbi podnositelji nisu prigovorili da im je Vrhovni sud povrijedio pravo na pristup sudu i pravično suđenje zbog različitih odluka Vrhovnog suda o reviziji u istom postupku. ESLJP je taj prigovor odbacio zbog neiscrpljivanja pravnog puta.

\subsubsection{Odluka Drljan protiv Hrvatske ${ }^{33}$}

Podnositelj je u zahtjevu ESLJP-u prigovorio da u kaznenom postupku protiv njega nisu bili zadovoljeni zahtjevi poštenog suđenja jer nije imao priliku ispitati svjedoke pozvane u ime optužbe. U ustavnoj tužbi nije se niti u biti pozvao na iste prigovore koje je iznio u zahtjevu ESLJP-u. U ustavnoj tužbi je naime prigovarao osnovama pritvora, kvaliteti pravnog zastupanja i ocjeni činjenica od strane domaćih sudova. Prema ocjeni ESLJP-a, suprotno načelu supsidijarnosti, podnositelj zahtjeva nije dao Ustavnom sudu ,priliku da mu pruži pravno sredstvo u odnosu na prigovore koje je podnio Sudu".

\subsubsection{Odluka Jurić protiv Hrvatske $e^{34}$}

Prvostupanjskom presudom usvojen je tužbeni zahtjev podnositeljice te je naloženo tuženiku da s podnositeljicom sklopi ugovor o kupoprodaji stana. Drugostupanjski sud usvojio je žalbu tuženika, te pozivom na članak 373.a Zakona

30 Predmet Vrtar protiv Hrvatske (presuda od 7. siječnja 2016., zahtjev br. 39380/13).

31 Predmet Vilić protiv Hrvatske (odluka od 12. prosinca 2017., zahtjev br. 59816/12).

32 Zakon o privremenom preuzimanju i upravljanju određenom imovinom, Narodne novine, broj $73 / 95$.

33 Predmet Drljan protiv Hrvatske (odluka od 25. ožujka 2010., zahtjev br. 34687/08).

34 V. bilj. 13. 
o parničnom postupku preinačio prvostupanjsku presudu i odbio tužbeni zahtjev podnositeljice. Pritom je ocijenio da prostor u kojem je podnositeljica zahtjeva stanovala nije stan, već prostorija za samce te da podnositeljica zahtjeva nikada nije stekla stanarsko pravo na predmetnom stanu, već samo pravo privremeno ga koristiti. Županijski sud naložio je iseljenje podnositeljice zahtjeva na temelju činjenice da nije imala pravnu osnovu za korištenje predmetnog prostora. Ustavnu tužbu podnositeljice Ustavni sud je odbacio zbog neiscrpljivanja dopuštenoga pravnog puta, odnosno nepodnošenja revizije Vrhovnom sudu.

U zahtjevu ESLJP-u podnositeljica je prigovorila da joj je odlukom o iseljenju povrijeđeno pravo na poštovanje doma te da su ju domaće vlasti, uskraćujući joj pravo na kupnju predmetnog stana, diskriminirale i povrijedile njezino pravo na mirno uživanje njezinog vlasništva. Pozvala se na članke 8. i 14. Konvencije kao i na članak 1. Protokola br. 1 uz Konvenciju.

ESLJPje pošao od članka 382. Zakona o parničnom postupku kojim je propisano da je revizija dopuštena ako drugostupanjski sud preinači prvostupanjsku presudu na temelju članka 373.a Zakona o parničnom postupku. Vezano za tvrdnje podnositeljice da je u nekim slučajevima Vrhovni sud odbacio revizije, iako je drugostupanjska presuda bila donesena na temelju članka 373.a Zakona o parničnom postupku, ESLJP je ponovio da samo postojanje sumnje u izglede za uspjeh određenoga pravnog sredstva koje nije očito uzaludno, nije dostatan razlog za propust iskorištavanja toga domaćeg pravnog sredstva. Činjenica da je Vrhovni sud u nekim slučajevima koji se odnose na primjenu članka 373a. Zakona o parničnom postupku odbacivao reviziju prema ocjeni ESLJP-a nije mogla osloboditi podnositeljicu obveze da u ovom predmetu iskoristi reviziju jer je to bio preduvjet za podnošenje ustavne tužbe. Naglasio je i da se domaća pravna sredstva moraju koristiti u skladu s formalnim pretpostavkama domaćeg prava i u propisanim rokovima. Suprotno stajalištu podnositeljice, obraćanjem Vrhovnom sudu podnositeljica bi stvorila priliku za razvoj domaće sudske prakse o predmetnim pitanjima, što bi potencijalno bilo korisno bilo kome drugom u sličnoj ili usporedivoj situaciji. ESLJP je zaključio da su razlozi koje je podnositeljica zahtjeva iznijela kako bi opravdala nepodnošenje revizije neuvjerljivi.

\subsubsection{Odluka Godler protiv Hrvatske ${ }^{35}$}

U zahtjevu ESLJP-u podnositelj je prigovorio neopravdanom odbijanju njegova zahtjeva za novčanu naknadu tijekom nezaposlenosti, pritom se pozivajući na članak 1. Protokola br. 1 uz Konvenciju. ESLJP je utvrdio da se na domaćoj razini podnositelj nikada nije pozvao na članak 1. Protokola br. 1, niti na zaštitu vlasništva na temelju članka 48. Ustava. Napomenuo je da se prema dosljednoj praksi Ustavnog suda, socijalna davanja smatraju imovinskim pravima na temelju Ustava te stoga nije bilo razloga da se podnositelj ne pozove na tu odredbu. Umjesto toga, podnositelj se u ustavnoj tužbi pozvao na članak 14. stavak 1. (zabrana diskriminacije), članak 19. stavak 2. (sudska kontrola zakonitosti upravnih akata), članak 26. (jednakost stranaca i državljana RH u postupku) i članak 29. stavak 1. (pravično suđenje) Ustava, koji u

35 Predmet Godler protiv Hrvatske (odluka od 20. veljače 2018., zahtjev br. 9440/12). 
biti nisu relevantni za njegove konkretne prigovore iznesene na temelju Konvencije. U ustavnoj tužbi podnositelj nije prigovorio povredi svojeg prava na poštovanje vlasništva, čak ni u biti. Umjesto toga, ograničio se na osporavanje tumačenja mjerodavnoga domaćeg prava i tvrdio je da je u tom pogledu bio diskriminiran, da nije izvršena sudska kontrola zakonitosti pojedinačnih akata upravnih vlasti i da je došlo do povrede njegovog prava na pošteno suđenje. ESLJP je ponovio svoje stajalište prema kojem, da bi pravilno iscrpili domaća pravna sredstva, nije dostatno da je povreda Konvencije ,jasna“ iz činjenica predmeta ili podnesaka podnositelja. Umjesto toga, podnositelji moraju stvarno iznijeti prigovor o tomu (izričito ili u biti) na način koji ne ostavlja sumnju da je prigovor, koji je kasnije podnesen ESLJP-u, stvarno bio istaknut na domaćoj razini.

U konkretnom slučaju prema zaključku ESLJP-a podnositelj nije pravilno iscrpio domaća pravna sredstva.

\subsection{Praksa Ustavnog suda Republike Hrvatske}

Iscrpljenost pravnog puta jedna je od postupovnih pretpostavki dopuštenosti ustavne tužbe ${ }^{36}$ Ako podnositelj ne iskoristi dopušteni pravni put, uključivo reviziju i upravni spor kad su dopušteni, ustavna tužba bit će odbačena. ${ }^{37}$ Riječ je o postupovnom rješenju.

Ustavna tužba bit će odbačena kao nedopuštena i ako podnositelj u prethodnom postupku nije koristio dopušteno pravno sredstvo. ${ }^{38}$ Primjer za to je prigovor povrede prava na suđenje u razumnom roku. Ustavnu tužbu podnesenu zbog povrede prava na suđenje u razumnom roku, ili prigovor povrede toga ustavnog prava iznesen u, tzv., „redovnoj” ustavnoj tužbi, Ustavni sud će odbaciti ako podnositelj ne dokaže da je koristio pravna sredstva za ubrzanje postupka koja su mu bila na raspolaganju dok je postupak trajao (najčešće će biti riječ o pravnim sredstvima propisanima Zakonom o sudovima). ${ }^{39}$

U ranijoj praksi Ustavni sud je isto postupao i s prigovorom diskriminacije. Od stupanja na snagu Zakona o suzbijanju diskriminacije ${ }^{40} 1$. siječnja 2009., ustavna tužba u svim predmetima vezanim za zaštitu prava na jednako postupanje odnosno zaštitu od diskriminacije dopuštena je samo nakon što navodna žrtva diskriminacije prethodno iscrpi dopušteni pravni put propisan tim zakonom. ${ }^{41}$ Kasnije je takvu praksu, odbačaja tog prigovora rješenjem (često sadržanim u odluci o meritumu), ${ }^{42}$

36 V. bilj 11.

37 V. primjerice rješenja U-III-3317/2003 od 30. siječnja 2004., U-III-2451/2007 od 26. rujna 2007. (www.usud.hr).

38 Članak 72. Ustavnog zakona glasi: "Ustavni sud će rješenjem odbaciti ustavnu tužbu: ... ako je ustavna tužba ... nedopuštena. Tužba je nedopuštena: ako nije iscrpljen dopušteni pravni put, odnosno ako podnositelj tužbe u prethodnom postupku nije koristio dopušteno pravno sredstvo...".

39 V. primjerice rješenje U-IIIA-322/2014 od 23. prosinca 2014., Narodne novine, broj 8/15. i odluku U-III-3467/2015 od 13. rujna 2018. (www.usud.hr).

40 Zakon o suzbijanju diskriminacije, Narodne novine, broj 85/08.

41 V. rješenje U-III-1097/2009 od 9. studenoga 2010., Narodne novine, broj 130/10.

42 V. primjerice odluku i rješenje U-III-7229/2014 od 5. ožujka 2015. (www.usud.hr). 
napustio, te sada u pravilu samo u obrazloženju konstatira da podnositelj nije dokazao da je koristio pravna sredstva propisana Zakonom o suzbijanju diskriminacije. ${ }^{43}$ Jedan od razloga napuštanja ranije prakse postupanja je i nedosljedna praksa Ustavnog suda vezana za prigovor diskriminacije na koju je ukazao i ESLJP u predmetu Pajić protiv Hrvatske. ${ }^{44}$ Predmet postupka koji je prethodio ustavnosudskom bio je zahtjev podnositeljice za odobrenje privremenog boravka u Republici Hrvatskoj zbog spajanja obitelji. Njezin zahtjev odbijen je s obrazloženjem da postojanje istospolne zajednice nije propisana osnova za odobravanje boravka strancu zbog spajanja obitelji. Ustavni sud je odbio ustavnu tužbu podnositeljice a u odnosu na prigovor diskriminacije, u obrazloženju je naveo da nije našao činjenice ili okolnosti koje bi na bilo koji način upućivale da je u postupku, koji je prethodio ustavnosudskom postupku, podnositeljica bila diskriminirana po bilo kojem svojstvu, pa je njezino pozivanje na povredu tog ustavnog jamstva ocijenio neosnovanim. Međutim, nastavno je napomenuo da podnositeljica nije dokazala da je prethodno koristila pravno sredstvo na temelju Zakona o suzbijanju diskriminacije, pri čemu se pozvao na rješenje kojim je odbacivši ustavnu tužbu, zauzeo stajalište o obvezi iscrpljivanja tog pravnog puta prije podnošenja prigovora o diskriminaciji Ustavnom sudu. Zaključno, utvrdio je da podnositeljici nije povrijeđeno pravo zajamčeno člankom 14. Ustava.

ESLJP je primijetio da Ustavni sud nije proglasio ustavnu tužbu podnositeljice nedopuštenom zbog neiscrpljenja domaćih pravnih sredstava, kao što je to bila praksa u drugim predmetima povezanim sa zahtjevima za zaštitu od diskriminacije, $u$ kojima podnositelji nisu pravilno iscrpili pravna sredstva pred nižim domaćim tijelima. Ustavni sud je naprotiv ocijenio da nije bilo povrede ustavnog prava podnositeljice na zaštitu od diskriminacije. U skladu s tim, iako je obrazloženje odluke Ustavnog suda donekle zbunjujuće, jer nije jasno kakvu je važnost pridao propustu podnositeljice da iskoristi posebnu parnicu predviđenu Zakonom o suzbijanju diskriminacije, ESLJP je ocijenio da je podnositeljica pravilno iskoristila pravna sredstva pred nadležnim domaćim tijelima, uključujući i pred Ustavnim sudom.

Ako podnositelj ustavnu tužbu podnese po iscrpljivanju dopuštenoga pravnog puta, međutim neki od prigovora istakne prvi put u ustavnoj tužbi, iako je imao mogućnost istaknuti ga tijekom postupka koji je prethodio ustavnosudskom, Ustavni sud ustavnu tužbu neće odbaciti zbog neiscrpljenosti pravnog puta, već, u pravilu, taj prigovor neće razmatrati.

\subsubsection{Ne bis in idem}

Prigovor povrede načela ne bis in idem jedan je od prigovora koje Ustavni sud neće razmatrati ako je istaknut prvi put u ustavnoj tužbi, a podnositelj je imao priliku taj prigovor istaknuti tijekom postupka koji je prethodio ustavnosudskom. Prema stajalištu Ustavnog suda taj prigovor može se postaviti prvi put u ustavnoj tužbi samo ako podnositelj taj prigovor nije mogao istaknuti ranije u postupku. Tu činjenicu Ustavni sud utvrđuje na temelju podataka iz spisa.

Primjerice, u odluci U-III-3775/2012 od 20. svibnja 2015., Ustavni sud je

43 V. primjerice odluku U-III-3418/2015 od 19. travnja 2018. (www.usud.hr).

44 predmet Pajić protiv Hrvatske (presuda od 23. veljače 2016., zahtjev br. 68453/13). 
utvrdio da je prekršajno rješenje (nalog) postalo pravomoćno 28. veljače 2010., dok je prvostupanjska presuda u kaznenom postupku donesena 20. listopada 2011., a drugostupanjska 27. travnja 2012. Ustavni sud je zaključio da je taj prigovor podnositelj mogao i bio dužan isticati u kaznenom postupku, a ne prvi put u ustavnoj tužbi podnesenoj u povodu kaznenih presuda. Slično i u odluci U-III-4902/2011 od 1. lipnja 2016. Prekršajni sud presudu je donio 18. rujna 2009., koja je isti dan stekla svojstvo pravomoćnosti. Prvostupanjska presuda u kaznenom postupku donesena je 17. veljače 2011., a drugostupanjska presuda, u povodu koje je podnesena ustavna tužba, 31. kolovoza 2011. Podnositelj je mogao, i bio je dužan, taj prigovor iznijeti pred kaznenim sudovima. Ili u odluci U-III-5923/2016 od 4. listopada 2017., u kojoj je podnositelj tužbu upravnom sudu (radi naplate trošarine) podnio poštom preporučenom pošiljkom 12. travnja 2016., a Općinski sud u Požegi je donio kaznenu presudu, broj: 2 K-60/14-6 dana 30. siječnja 2015., koja je postala pravomoćna 17. kolovoza 2015. Podnositelj nije u tužbi upravnom sudu, niti u žalbi na prvostupanjsku presudu upravnog suda istaknuo prigovor povrede načela ne bis in idem, iako je taj prigovor mogao i bio dužan isticati u upravnom postupku, budući da je u trenutku podnošenja upravne tužbe (12. travnja 2016.) presuda u kaznenom postupku bila pravomoćna (17. kolovoza 2015). ${ }^{45}$

\subsubsection{Nepristranost suda}

Kao i kod prigovora povrede načela ne bis in idem, Ustavni sud neće razmatrati prigovor pristranosti suda ako ga je podnositelj propustio istaknuti u postupku koji je prethodio ustavnosudskom.

U odluci U-III-458/2011 od 19. studenoga 2015. Ustavni sud nije razmatrao prvi put u ustavnoj tužbi istaknuti prigovor pristranosti predsjednice prvostupanjskog vijeća i člana drugostupanjskog žalbenog vijeća. Ako je podnositelj smatrao da razlozi za izuzeće tih sudaca postoje, bio ih je dužan, prema ocjeni Ustavnog suda, istaknuti u žalbenom postupku, odnosno na sjednici drugostupanjskog vijeća održanoj pred Vrhovnim sudom.

Slično i u odluci U-III-4626/2017 od 21. ožujka 2018. Podnositelj je u ustavnoj tužbi iznio prigovore o sudjelovanju dvoje sudaca Županijskog suda u postupku odlučivanja o njegovoj žalbi podnesenoj protiv presude Općinskog suda. Uvidom u reviziju koju je podnositelj protiv presude Županijskog suda podnio Vrhovnom sudu Ustavni sud utvrdio je da ti prigovori nisu uvršteni u njezin sadržaj. Slijedom utvrđenja da te prigovore podnositelj prvi put navodi tek u ustavnoj tužbi, Ustavni sud o istima nije odlučivao.

\subsubsection{Neučinkovitost branitelja po službenoj dužnosti}

U predmetu U-III-7454/2014 (odluka od 17. veljače 2016.) podnositelj je podnio ustavnu tužbu u povodu presuda kojima je proglašen krivim zbog počinjenja kaznenog djela ubojstva u pokušaju i osuđen na kaznu zatvora u trajanju od sedam godina. Jedan

45 Vezano uz primjenjivost načela ne bis in idem u upravnim stvarima radi naplate trošarine v. U-III-5981/2016 od 27. lipnja 2017., Narodne novine, broj 77/17. 
od prigovora iz ustavne tužbe odnosio se na nezadovoljstvo braniteljem po službenoj dužnosti. U ustavnoj tužbi podnositelj je istaknuo da je "upozoravao sud prvog stupnja radi promjene odvjetnika po službenoj dužnosti koji nije poduzeo ništa u vezi toga da ga zamijene jer je branitelj očito nemarno postupao prema meni”. U odnosu na taj prigovor, Ustavni sud je nakon uvida u kazneni spis utvrdio da podnositelj tijekom provedenoga kaznenog postupka nije sudu iznosio (usmeno na glavnim raspravama i/ ili u pisanom obliku) primjedbe na (ne)rad svog branitelja (po službenoj dužnosti) i/ili na neslaganja oko (strategije) obrane, a niti je to učinio u žalbi protiv prvostupanjske presude. S obzirom na to da je te prigovore podnositelj iznio prvi put u ustavnoj tužbi, Ustavni sud ih nije posebno razmatrao.

\subsubsection{Pravo na obranu uz branitelja}

U predmetu U-III-6308/2014 (odluka od 11. svibnja 2016.) podnositelj je podnio ustavnu tužbu u povodu presude kojom je utvrđeno da je podnositelj u stanju neubrojivosti u stjecaju počinio više kaznenih djela, te mu je određen prisilni smještaj u psihijatrijsku ustanovu. Jedan od prigovora koji je iznio u ustavnoj tužbi bio je prigovor da mu je bila „onemogućena zakonom propisana obrana” po branitelju koji mu je dodijeljen po službenoj dužnosti. Ustavni sud utvrdio je da podnositelj nije tijekom postupka, kao niti u žalbi protiv prvostupanjske presude isticao navedeni prigovor. Slijedom tog utvrđenja, smatrao je da se na ove okolnosti ne može osnovano pozivati kao na razloge zbog kojih bi došlo do povrede njegovih ustavnih prava koje navodi u ustavnoj tužbi.

U predmetu U-III-2411/2011 (odluka od 9. srpnja 2014.) podnositelj je podnio ustavnu tužbu u povodu presuda kojima je proglašen krivim i osuđen zbog kaznenog djela zlouporabe položaja i ovlasti. U ustavnoj tužbi prvi je put istaknuo prigovor da mu je „onemogućena zakonom propisana obrana”, s obzirom na to da mu je kao branitelj po službenoj dužnosti dodijeljen odvjetnik (B. K. - „nametnut od strane predsjednika vijeća”), kojem je otkazao punomoć zbog toga što mu je „onemogućio pravno relevantnu obranu". Budući da podnositelj nije tijekom postupka, kao niti u žalbi protiv prvostupanjske presude isticao navedeni prigovor, Ustavni je sud smatrao da se na ove okolnosti ne može osnovano pozivati kao na razloge zbog kojih bi došlo do povrede njegovih ustavnih prava koje navodi u ustavnoj tužbi.

Također, Ustavni sud je uvidom u kazneni spis utvrdio da je podnositelj 17. svibnja 2006. podneskom otkazao punomoć odvjetniku B. K.-u radi nemogućnosti plaćanja odvjetničkih usluga uz zamolbu da mu sud dodijeli odvjetnika po službenoj dužnosti. Na glavnoj raspravi 2. listopada 2006. podnositelj je izjavio da je suglasan da ga tijekom daljnjeg postupka zastupa postavljeni branitelj po službenoj dužnosti (isti) odvjetnik B. K.

\subsubsection{Razni prigovori postupovne naravi}

U predmetu U-III-3753/2011 (odluka od 13. studenoga 2014.) podnositelj je u ustavnoj tužbi istaknuo i prigovor da ,prvostupanjski sud nije smio saslušati tužitelja u parničnom postupku kao stranku na ročištu na koje podnositelj nije pristupio zbog 
toga što nisu bile ispunjene pretpostavke za izvođenje dokaza saslušanjem stranaka". Taj je prigovor prvi put istaknuo u ustavnoj tužbi. S obzirom na to da podnositelj nije tijekom postupka, niti u žalbi protiv prvostupanjske presude isticao navedeni prigovor, Ustavni je sud smatrao da se na ove okolnosti ne može osnovano pozivati kao na razloge zbog kojih bi došlo do povrede ustavnog prava na pravično suđenje, osobito jer je predložio održavanje pripremnog ročišta u njegovoj odsutnosti.

U radnom sporu (odluka U-III-4304/2011 od 15. listopada 2014.) podnositeljica je osporila presude kojim je odbijen njezin tužbeni zahtjev za poništaj otkaza ugovora o radu. Podnositeljica je u ustavnoj tužbi, između ostalih, istaknula i prigovor da je tijekom parničnog postupka nije zastupala stručna osoba te da je sud nije upozorio da može imati besplatnog odvjetnika zbog lošeg imovnog stanja. Navedene prigovore podnositeljica je prvi put istaknula u ustavnoj tužbi. S obzirom da podnositeljica nije tijekom postupka, u žalbi protiv prvostupanjske presude, kao niti u reviziji protiv drugostupanjske presude isticala navedene prigovore, Ustavni sud je smatrao da se na ove okolnosti ne može osnovano pozivati kao na razloge zbog kojih bi došlo do povrede ustavnih prava na pravično suđenje.

U predmetu U-III-3659/2015 (odluka od 13. prosinca 2017.) podnositelji su podnijeli ustavnu tužbu u povodu presude Visokog upravnog suda Republike Hrvatske u upravnoj stvari radi objavljivanja ponude za preuzimanje društva. Jedan od prigovora podnositelja bio je da su zbog neodržavanja usmene rasprave pred Hrvatskom agencijom za nadzor financijskih usluga onemogućeni u ostvarivanju svog prava na sudjelovanje u postupku. Uvidom u osporene akte te mjerodavnu dokumentaciju iz spisa Ustavni sud utvrdio je da podnositelji navedeni prigovor (neodržavanje usmene rasprave) prvi put iznose u ustavnoj tužbi. Naime, u postupku koji je prethodio ustavnosudskom postupku podnositelji su isticali prigovor nemogućnosti raspravljanja, ali ne i prigovor neodržavanja usmene rasprave.

U tzv. pritvorskom predmetu (odluka U-III-4077/2018 od 28. studenoga 2018.) jedan od prigovora podnositeljice bio je da se osporena rješenja ne mogu temeljiti na psihijatrijskom vještačenju jer ga je sačinio vještak psihijatar koji je bio zaposlen u psihijatrijskoj ustanovi u kojoj je podnositeljica liječena. Ustavni sud utvrdio je da je taj prigovor podnositeljica prvi put istaknula tek u ustavnoj tužbi, zbog čega ga Ustavni sud nije razmatrao.

Rješenjem U-III-902/2008 od 20. siječnja 2011. Ustavni sud odbacio je ustavnu tužbu (tzv. meritorni odbačaj). U vezi s prigovorom podnositelja glede nepropisnog sastava prvostupanjskog suda, kao bitne povrede odredaba kaznenog postupka, utvrdio je da taj prigovor ističe prvi put u ustavnoj tužbi. Uvidom u kazneni spis Ustavni sud utvrdio je da je podnositelj tijekom trajanja kaznenog postupka imao, i propustio, dvije prigode za isticanje takvih prigovora (na glavnoj raspravi pred prvostupanjskim sudom i u žalbi na presudu). Pritom se pozvao na stajališta u citiranim odlukama U-III-857/2008 i U-III-2374/2009, prema kojem je podnositelj, koji pred redovnim sudom propusti iznijeti prigovore postupovne naravi, a iznosi ih prvi put u ustavnoj tužbi, „bitno umanjio mogućnost redovnih sudova da reagiraju na eventualne povrede zakona, uslijed čega činjenica neiscrpljenosti pravnog puta još više poprima na važnosti”. 


\subsubsection{Blaži zakon}

Kao jedan od, za ovaj rad, zanimljivih primjera navodimo i odluku u povodu ustavne tužbe, u kojoj je (U-III-2387/2011) podnositelj prvi put istaknuo prigovore o tomu da su sudovi, s obzirom na vrijeme počinjenja kaznenih djela za koja je optužen, trebali primijeniti Krivični zakon RH te da su sudovi pogrešno primijenili materijalno pravo jer nisu primijenili blaži zakon. Budući da podnositelj nije tijekom kaznenog postupka, kao niti u žalbi protiv prvostupanjske presude isticao navedene prigovore, Ustavni sud je ocijenio da se na ove okolnosti ne može osnovano pozivati kao na razloge zbog kojih bi došlo do povrede njegovih ustavnih prava koje je naveo u ustavnoj tužbi.

\subsubsection{Ostali prigovori}

Ustavni sud je u odluci U-III-3727/2015 od 21. listopada 2015. naveo da: „Podnositelj nije u ustavnoj tužbi naveo razloge zbog čega nije prigovore vezane uz formu darovnog ugovora iznio tijekom parničnog postupka, niti zbog čega ih tek sada iznosi (iako je tužba podnesena još 2008.). Navedeni prigovor podnositelj prvi put ističe u ustavnoj tužbi. S obzirom da podnositelj nije tijekom postupka, niti u žalbi protiv prvostupanjske presude, a ni u reviziji isticao navedeni prigovor, Ustavni sud smatra da se na ove okolnosti ne može osnovano pozivati kao na razloge zbog kojih bi došlo do povrede njegovog ustavnog prava koje navodi u ustavnoj tužbi. Stoga nije osnovano ni pozivanje podnositelja na odluke Ustavnog suda (navedene u točki 3.1. obrazloženja ove odluke) jer su one donesene u parničnim postupcima u kojima se raspravljalo samo o formi darovnog ugovora". Dok je u odluci U-III-2448/2011 od 9. srpnja 2014. utvrđenje Ustavnog suda: „U ustavnoj tužbi podnositeljica po prvi put ističe prigovor o tome da su sudovi pogrešno primijenili na konkretan slučaj Kazneni zakon koji je stupio godinu i pol nakon navodnog izvršenja kaznenog djela". S obzirom da podnositeljica nije tijekom postupka, kao niti u žalbi protiv prvostupanjske presude isticala navedeni prigovor, Ustavni sud smatra da se na ove okolnosti ne može osnovano pozivati kao na razloge zbog kojih bi došlo do povrede njezinih ustavnih prava koje navodi u ustavnoj tužbi." U odluci U-III-2447/2011 od 9. srpnja 2014. istaknuto je: „Nadalje, u ustavnoj tužbi podnositelj po prvi put ističe prigovor o tome da su sudovi pogrešno u konkretnom slučaju primijenili zakonske odredbe o stjecaju, smatrajući da nije mogao počiniti dva odvojena kaznena djela u stjecaju već jedno zbirno kazneno djelo. S obzirom da podnositelj nije tijekom postupka, kao niti u žalbi protiv prvostupanjske presude isticao navedeni prigovor, Ustavni sud smatra da se na ove okolnosti ne može osnovano pozivati kao na razloge zbog kojih bi došlo do povrede njegovih ustavnih prava koje navodi u ustavnoj tužbi."

\section{ZAKLJUČNO}

Ističući važnost interpretativne uloge i ESLJP-a i Ustavnog suda u praćenju sveukupnog životnog napretka te tako pojačavanju kvalitete i širine zaštite ljudskih prava i temeljnih sloboda, kroz njihova navedena stajališta, kontinuirano se pronalaze 
nove teme koje je potrebno isticati s konvencijskog i ustavnog aspekta. Zbog načela supsidijarnosti, koje je praksa sudova jasno definirala, a na kojem se temelji sustav zaštite ljudskih prava i temeljnih sloboda, prigovore materijalne naravi, kao što su npr. povreda prava vlasništva, poštovanje privatnog i obiteljskog života, pravo na dom, pravo na rad, sloboda izražavanja, okupljanja, udruživanja i dr., treba isticati tijekom redovnog postupka, a postupovni prigovor, npr. pristranosti prvostupanjskog suca, potrebno je isticati čim ga je moguće istaknuti. Važnost tog načela posebno je naglašena usvajanjem Protokola br. 15 uz Konvenciju kojim se dopunjuje Preambula Konvencije novom alinejom: ,potvrđujući da visoke ugovorne stranke, u skladu s načelom supsidijarnosti, imaju prvenstvenu odgovornost osigurati prava i slobode određene u ovoj Konvenciji i Protokolima uz Konvenciju i da pri tome one uživaju slobodu procjene pod nadzorom Europskog suda za ljudska prava osnovanog ovom Konvencijom". ${ }^{46}$

\section{LITERATURA}

Knjige i članci:

1. Crnić, Jadranko, Uloga Ustavnog suda Republike Hrvatske u zaštiti temeljnih ljudskih prava i sloboda: postaje li Ustavni sud ,usko grlo“ u ostvarivanju ustavnog prava na pravično suđenje u razumnom roku, Hrvatska pravna revija, 5/2005., 1, str. 1-8.

2. Marković, Sandra, Trgovac, Sanja, Nova praksa u postupanju Ustavnog suda Republike Hrvatske, Pretpostavke za odlučivanje o ustavnim tužbama, Informator, broj 5844, od 10. ožujka 2010.

3. Marković, Sandra, Trgovac, Sanja, Ustavna tužba i zahtjev Europskom sudu za ljudska prava-analiza i značaj tih pravnih sredstava, u: Aktualnosti hrvatskog zakonodavstva i pravne prakse, Godišnjak 25, Organizator, 2018.

4. Omejec, Jasna, Konvencija za zaštitu ljudskih prava i temeljenih sloboda u praksi Europskog suda za ljudska prava, strasbourški acquis, Zagreb, Novi informator, 2013.

5. S Šrin, Duška, Nastanak hrvatskoga Ustava, Zagreb, Narodne novine, 1997.

Pravni propisi u sudska praksa:

1. Konvencija za zaštitu ljudskih prava i temeljnih sloboda, Narodne novine - Međunarodni ugovori, broj 18/97., 6/99. - pročišćeni tekst, 8/99. - ispravak, 14/02. i 1/06.

2. Odluka U-III-1897/2014 od 18. svibnja 2016., www.usud.hr.

3. Odluka broj: U-III-2374/2009 od 4. listopada 2010., Narodne novine, broj 119/10.

4. Odluka U-I- U-I-448/2009 i dr. od 19. srpnja 2012., Narodne novine, broj 91/12.

5. Odluka USRH broj: U-III-4150/2010 i dr. od 12. siječnja 2015., Narodne novine, broj 6/15.

6. Predmet Chapman protiv Ujedinjenog Kraljevstva [GC], br. 27238/95, stavak 91., ECHR 2001-I.

7. Predmet Drljan protiv Hrvatske, odluka od 25. ožujka 2010., zahtjev br. 34687/08.

8. Predmet ESLJP-a Jurić protiv Hrvatske, odluka od 26. lipnja 2018., zahtjev br. 29843/13, $\S 19$.

9. Predmet ESLJP-a Srbić protiv Hrvatske, odluka od 21. lipnja 2011., zahtjev br. 4464/09.

10. Predmet Gherghina protiv Rumunjske, presuda Velikog vijeća od 9. srpnja 2015., zahtjev br. $42219 / 07$.

46 Protokol br. 15 još nije stupio na snagu; Republika Hrvatska ga je potpisala i potvrdila (Narodne novine - Međunarodni ugovori, broj 13/17.). 
11. Predmet Godler protiv Hrvatske, odluka od 20. veljače 2018., zahtjev br. 9440/12.

12. Predmet Josip Habulinec i Anita Filipović protiv Hrvatske, odluka od 4. lipnja 2013., zahtjev br. 51166/10.

13. Predmet Jureša protiv Hrvatske, odluka od 22. svibnja 2018., zahtjev br. 24079/11, §19.

14. Predmet Jurišić protiv Hrvatske, odluka od 23. kolovoza 2016., zahtjev br. 29555/11.

15. Predmet Merot d.o.o. i Storitve TIR d.o.o., odluka od 10. prosinca 2013., zahtjevi br. 29426/08 i 29737/08.

16. Predmet Orlić protiv Hrvatske, presuda od 21. lipnja 2011., zahtjev br. 48833/07.

17. Predmet Paulić protiv Hrvatske, presuda od 22. listopada 2009., zahtjev br. 3572/06.

18. Predmet Pavlović $i$ dr. protiv Hrvatske, presuda od 2. travnja 2015., zahtjev br. 13274/11.

19. Predmet Sisojeva and Others protiv Latvije [GC], br. 60654/00, stavak 90., ECHR 2007-II.

20. Predmet Swedish Engine Drivers' Union protiv Švedske, od 6. veljače 1976., stavak 50., Serija A br. 20.

21. Predmet Šimunovski protiv Hrvatske, odluka od 21. lipnja 2011., zahtjev br. 42550/08.

22. Predmet Vilić protiv Hrvatske, odluka od 12. prosinca 2017., zahtjev br. 59816/12.

23. Predmet Vrtar protiv Hrvatske, presuda od 7. siječnja 2016., zahtjev br. 39380/13.

24. Predmet Vučković $i$ drugi protiv Srbije, presuda Velikog vijeća od 25. ožujka 2014., zahtjevi br. 17153/11 i dr.

25. Predmet Znamenskaya protiv Rusije, presuda od 2. lipnja 2005., zahtjev br. 77785/01.

26. Rješenja U-III-3317/2003 od 30. siječnja 2004., U-III-2451/2007 od 26. rujna 2007., www.usud.hr-

27. Rješenje U-III-1118/2015 od 30. ožujka 2016., www.usud.hr.

28. Rješenje USRH broj: U-III-1747/2009 od 10. studenoga 2009., Narodne novine, broj $139 / 09$.

29. Ustav Republike Hrvatske, Narodne novine 56/90., 135/97., 113/00., 28/01., 76/10. i 5/14. 


\author{
Sandra Marković* \\ Sanja Trgovac**
}

\title{
Summary
}

\section{STRESSING THE RIGHTS GUARANTEED BY THE CONSTITUTION AND CONVENTION IN THE PROCEEDINGS BEFORE ORDINARY COURTS}

The ECtHR's position is that the subsidiarity principle is one of the fundamental principles upon which the supervisory system of the Convention is based. This specifically means that the mechanism for the protection of human rights and fundamental freedoms established by the Convention is subsidiary to national human rights protection systems. This paper focuses on the period when all parties in court proceedings had to understand and accept the importance of the application of the Convention for the Protection of Human Rights and Fundamental Freedoms, as well as of the Constitution of the Republic of Croatia in proceedings before ordinary courts. The importance of these two documents is expressed in the decisions of the Constitutional Court of the Republic of Croatia and those of the European Court of Human Rights, which, with their role as interpreters of the Convention and of the Constitution respectively, clearly defined the contents of individual constitutional and Convention rights, freedoms, guarantees and principles, and created guidance for their better protection. The advantages of stressing violations of Convention and constitutional rights, even during proceedings before ordinary courts, are indisputable, and this paper also stresses their obligatory nature, in situations where parties strive with their requests to appear before courts of these instances. The authors, who have been dealing with constitutional and Convention law throughout their careers, have followed the development of the case law of these courts, especially of the Constitutional Court, and thus noticed the development of stricter criteria of both courts when deciding on the merits in individual cases. In this paper, the authors focus on Constitutional Court and ECtHR decisions where the principle of subsidiarity is more prominent. They clarify the importance of a constitutional complaint, as well as the status of constitutional adjudication compared to ordinary court proceedings, and the shift of the Constitutional Court to constitutional argumentation in place of the argumentation of an ordinary court, which prevailed in the earlier jurisprudence of the Constitutional Court. In this context, it is possible to still perceive the insufficient "usage" of Constitutional Court and Convention arguments, as well as the incorrect argumentation of the constitutional complaint and of references to the European Court with regular appellate reasoning.

\footnotetext{
* Sandra Marković, Ph.D., lawyer, Joint Law Office dr. sc. Sandra Marković and Sidonija Grbavac; sandra.markovic@mgg-law.eu.

** Sanja Trgovac, dipl. iur., Head of the Counseling Service of the Constitutional Court of the Republic of Croatia; sanja_trgovac@usud.hr.
} 
Keywords: Constitutional Court; ECtHR; Convention; Constitution; subsidiarity principle; Protocol 15; Convention law; constitutional complaint; reference to the ECtHR; argumentation.

Zussamenfassung

\section{HERVORHEBUNG VON VERLETZUNGEN DER KONVENTIONS- UND VERFASUNGSRECHTE VOR ORDENTLICHEN GERICHTEN}

Der Ansicht des EGMR nach ist der Grundsatz der Subsidiarität eine der grundlegenden Prinzipien, auf welchen sich das Kontrollesystem der Konvention stützt. Konkret beduetet das, dass der Mechanismus des durch die Konvention eingerichteten Schutzes der Menschenrechte und Grundfreiheiten den nationalen Systemen des Schutzes von Menschenrechten gegenüber subsidiär ist. Der Beitrag bespricht den Zeitablauf, nach welchem alle Parteien des Gerichtsverfahrens die Wichtigkeit der Anwendung der Europäischen Konvention zum Schutz der Menschenrechte und Grundfreiheiten, aber auch der Verfassung der Republik Kroatien in Verfahren vor ordentlichen Gerichten begreifen und akzeptieren sollten. Die Wichtigkeit dieser zwei Dokumente wird im Beitrag durch die Entscheidungen des Verfassungsgerichts der Republik Kroatien und des Europäischen Gerichtshofs für Menschenrechte konkretisiert, die durch ihre Rollen als Ausleger der Konvention, beziehungsweise der Verfassung, die Inhalte einzelner Verfassungs- und Konventionsrechte, Freiheiten, Gewährleistungen und Grundsätze klar definiert haben und somit den Wegweiser für einenbesseren Schutzbegründethaben.DieVorteile derHervorhebung von Verletzungen der Konventions- und Verfassungrechte während des Verfahrens vor ordentlichen Gerichten sind unumstritten. Der Beitrag schlägt vor, dass das unumgänglich sein sollte, vor allem in Situationen, in welchen die Parteien mit ihren Ansprüchen schwieriger zu Gerichten dieser Instanzen kommen. Da sich die Autorinnen dieses Beitrags professionel mit dem Verfassungs- und Konventionsrecht beschäftigen, können sie die Praxis dieser Gerichte, insbesondere des Verfassungsgerichts, folgen. Dabei bemerkten sie, dass die Kriterien beider Gerichte für meritorische Entscheidungen in einzelner Rechtsaachen verschärft wurden. Besonderes Augenmerk gilt dabei den Entscheidungen des Verfassungsgerichts und des EGMR, in welchen der Grundsatz der Subsidiarität angewendet wurde. Die Verfassungklage und der Stellenwert der Verfassungsgerichtsbarkeit den ordentlichen Gerihctsverfahren gegenüber wird erklärt. Dabei wird betont, dass das Verfassungsgericht von Argumentierung ordentlicher Gerichtsbarkeit, welche in der früheren Verfassungsrechsprechung dominierte, auf Verfassungargumentierung wechselte. In diesem Kontext bemerkt man, dass die verfassungs- und konventionsrechtliche Argumente immer noch ungenügend benutzt werden sowie auch dass die Verfassungsklage und die Beschwerden an den EGMR durch Berufungsgründe falsch argumentiert werden. 
Schlüsselwörter: Verfassungsgericht; EGMR; Konvention; Verfasssung; Grundsatz der Subsidiarität; Protokoll Nr. 15; Konventionsrecht; Verfassungsrecht; Verfassungsklage; Beschwerde an den EGMR; Argumentation.

Riassunto

\section{IL RILIEVO DELLE VIOLAZIONI DEI DIRITTI CONVENZIONALI E COSTITUZIONALI NEI PROCEDIMENTI DINNAZI AI TRIBUNALI ORDINARI}

Secondo l'orientameto della CEDU il principio di sussidiarietà costituisce uno dei principi fondamentali sui quali posa il sistema di controllo della Convenzione. In concreto ciò significa che il meccanismo di protezione dei ditritti dell'uomo e delle libertà fondamentali concepito dalla Convenzione ha carattere sussidiario rispetto ai sistemi nazionali di tutela dei diritti umani. Nel lavoro si evidenzia l'intervallo di tempo che è servito alle parti processuali nei contenziosi per capire ed accettare l'importanza dell'applicazione della Convenzione per la salvaguardia dei diritti dell'uomo e delle libertà fondamentali, come pure della Costituzione della Repubblica di Croazia nei procedimenti dinnanzi ai tribunali ordinari. L'importanza di queste due fonti si manifesta attraveso le pronunce della Corte costituzionale della Repubblica di Croazia e della Corte europea dei diritti dell'uomo, che nella veste di interpreti della Convenzione e della Costituzione hanno definito chiaramente i contenuti di determinati diritti, libertà, garanzie e principi costituzionali e convenzionali, indicando la via per la loro idonea tutela. Il vantaggio del rilievo delle violazioni dei diritti convenzionali e costituzionali già dinnazi ai tribunali ordinari è indubbio, e nel lavoro se ne sottolinea anche l'obbligatorietà, nelle situazioni nelle quali le parti con le loro domande intendano in realtà giungere a tali istanze. Le autrici, occupandosi professionalmente di diritto costituzionale e convenzionale, seguono l'evoluzione della giurisprudenza di dette corti, in particolare della Corte costituzionale, osservando altresì la crescente rigorosità dei criteri di entrambe le corti nel valutare nel merito singoli casi. Nel lavoro si pone l'accento sulle pronunce della Corte costituzionale e della CEDU nelle quali sia emersa l'applicazione del principio di proporzionalità. Si precisa il significato del ricorso costituzionale e la posizione della giustizia costituzionale rispetto ai tribunali ordinari, osservando il passaggio della Corte costituzionale all'argomentazione costituzionale rispetto a quella ordinaria, la quale prevalse per un certo periodo. In tale constesto si osserva e si nota l'ancora insufficiente „utilizzo“ delle argomentazioni costituzionali e convenzionali e l'errata argomentazionme del ricorso costituzionale e dei ricorsi dinnanzi alla Corte europea fondati su motivi impugnatori ordinari. 
Parole chiave: Corte costituzionale; CEDU; Costituzione; principio di sussidiarietà; Protocollo 15; diritto convenzionale; diritto costituzionale; ricorso costituzionale; ricorsco dinnanzi alla CEDU; argomentazione. 